\title{
The Role Of The Northern League In Transforming The Italian Political System: From Economic Federalism to Ethnic Politics and Back
}

\section{Francesco Cavatorta}

\section{$\underline{\text { Introduction }}$}

Until the early 1990s, Italy displayed a stable party system, where newcomers found it particularly difficult to challenge the overwhelming influence of the traditional parties: Christian Democrats (DC), Socialist Party (PSI), and Communist Party (PCI). New political formations managed to emerge, but they were largely unable to sustain their electoral success over a long period of time and failed to establish themselves as credible alternatives. ${ }^{1}$ The appearance of the Northern League (NL) in the late 1980s was also treated as temporary disaffection of sectors of the electorate from traditional politics. However, this proved not to be the case and the NL went on to become a very central player in the political system.

This article examines the conditions for the emergence of the Northern League and its long lasting impact on Italian politics. The Northern League is partly responsible for major changes that occurred in Italy over the last decade and while its electoral fortunes have somewhat declined in recent years, the issues it brought to prominence are today very much central in political debates. The article argues that the NL, far from being a single-issue party, has a clear vision of what Italy in the new millennium should look like. Moreover, the article argues that this vision is similar to the one held by a number of right-wing parties in Western Europe such as Haider's Freedom Party. Accordingly, the NL has abandoned its pro-independence position and has entered again into a political and electoral alliance with the centre-right Berlusconi-led coalition. This coalition is the favourite to win the 2001 national election and the NL is likely to hold once again a number of key ministerial posts. The presence of the Northern League in the new government will certainly accelerate the pace of decentralising reforms. The initial goal of federalism will probably be achieved after the NL went through a stage of profound radicalisation within which it flirted will independence. The failure of the Padanian project 
conceived in ethnic terms has brought the NL back to its roots and it is likely that Italy will soon be a federal state.

\section{International factors and their impact on the Italian political system}

The emergence of the Northern League can be understood only by taking into account the collapse of the bipolar international order and its effects on the Italian political system. The stability of the system centred on the necessity of keeping the Communist Party out of power in order for Italy to remain firmly anchored to the Western camp. ${ }^{2}$ To achieve this goal, all parties would enter a Grand Coalition rather than having the PCI share government responsibilities. This Grand Coalition was not necessary in the aftermath of World War II, as the DC was able to win the majority of seats in Parliament. The situation eventually changed, as support for the DC decreased while other smaller parties were making electoral progress. Thus, since the mid 1960s a coalition between the DC, the PSI and other minor parties was in power. In order to maintain their position, the parties in government implemented a system of close control of the state apparatus, fostering a network of patronage and clientelism to perpetuate their hold on public affairs. This led the political class to widespread corruption, chronism, mismanagement of public resources, ties to organised crime, and lack of national consciousness. At the same time, "vast sectors of the entrepreneurial and professional classes supported the parties in government in exchange for the authorities' blind eye when it came to fiscal, environmental, and safety regulations." ${ }^{3}$ In short, Italy traded good government for political stability. ${ }^{4}$ Nevertheless, stability was effective in keeping the Communists out of government and in guaranteeing strong economic growth. Thus, the outstanding economic results, particularly in the North, and political stability counterbalanced the 'side-effects'.

On the other side of the spectrum was the Communist opposition. Through the years the PCI had been able to attract constantly one third of the electorate: not enough to govern, but enough to gain important concessions. The government and the opposition worked together on 
very sensitive issues to implement specific reforms, leading to the belief that the PCI itself was profiting from the system. Nevertheless, Italian politics, "frozen" ${ }^{5}$ in the aftermath of WW II, was divided on a left/right cleavage and other fractures that might have determined a different partystructure were subordinate to the ideological struggle. Thus, "the territorial conflict within Italy found no direct expression in the party system." ${ }^{6}$

In this context came the collapse of communism. The most important justification for the DC's rule and for its internal cohesion was found in its ideological confrontation with the Marxist sub-culture and the fall of the Soviet Union undermined its role. The DC was unable to produce an innovative project to lead Italy forward, its recent governing record was very questionable and the extension of corruption scandals that struck the party at every level buried the DC's remaining legitimacy. The fall of the Berlin Wall had great repercussions on the PCI as well and the party broke up in 1991. The majority of party members accepted the leadership's decision to fully embrace social democracy; while a small number of hard-liners went on to form a new communist party. Thus, in the early 1990s the two largest Italian parties were left without any ideological legitimacy and accused of having led the country to ruins. The PSI as well disappeared under the weight of corruption scandals. According to the NL, all traditional parties were one and the same. Luciano Costantini argues that in the NL discourse "parties are all the same because they are all in favour of centralism and because they want to deprive the rich regions of their wealth through an unfair tax system and through an Southernised bureaucracy.", This climate of political incertitude and loss of trust toward the mass parties favoured the sudden expansion of the Northern League.

Thus, international political events contributed to liberate the Italian electorate from the old voting pattern and provoked deep changes. Renato Mannheimer argues that "three processes closely intertwined had a relevant role in determining the decline of consensus for traditional parties" $^{\prime 8}$ : the decreasing importance of 'sub-cultural traditions which deeply affected electoral choices by perpetuating particular values, myths and symbols; the decreasing influence of the 
left/right dimension in looking at or dealing with certain issues; and the loss of faith in the role of traditional parties. Thus, the old cleavage disappeared and the NL correctly identified the new one in the North/South differences. The politics of the 'white' ${ }^{9}$ northern regions that "had been held politically hostage" ${ }^{10}$ by the Cold War was at last freed. However, the end of the international ideological struggle was a necessary, but not sufficient cause to produce the League's victories.

Since the late 1980s the international economic order had undergone substantial changes in its structure and modes of production. The end of the Cold War accelerated those changes by eliminating the alternative economic model. Increasing global exchanges, an acceleration of the technological revolution, and the importance of the 'financial' economy apparently limit the effective intervention of governments in the economy. After the collapse of socialist models and the long-term growth of the American economy, the Anglo-American model has become, it appears, the only efficient economic organisation. Global competition dramatically increased, production moves from one country to another in search of the lowest cost of labour while the financial market decides the economic fate of many countries.

"The move from a Fordist mode of production, that had contributed to create in Western Europe a net of protection for the working class, to a post-Fordist world dramatically changed all social and economic relationships." ${ }^{11}$ Italian entrepreneurs such as the former president of Confindustria (the association of Italian patrons) Giorgio Fossa, economists such as the European Union Commissioner Mario Monti, and many politicians believe that the Anglo-American model needs to be copied. In order to stay competitive on the world market, they call for much less state intervention, free hand in dealing with the labour force, improvement of all infrastructures, possibility to move goods and capitals without restraint, and a dramatic decrease of state expenditures. Thus, the end of the ideological war and the revolutionary impact of economic globalization's forces determined the rise of new issues and demands that needed to find a political channel. 
The inability to manage the political and economic crisis of the late 1980s and early 1990s was particularly evident in the 'deep North', a very dynamic regional economy. In the area, there are a vast number of entrepreneurs employing few people and engaged on international markets that are in search of political representation since they have become the protagonists of the global economy. Relations between these entrepreneurs and the DC-led central government were previously regulated on a simple assumption: the rich North provided enough money to Rome in exchange for being left alone. Thus, the government tolerated massive tax evasion, exemption from safety regulations, and predatory investments in the Southern regions of the country through a policy of tax breaks. In exchange, support for the DC and the PSI would remain firm and no particular attention would be paid to how state money would be spent, particularly in the South. Workers in these small and medium sized firms were and are not heavily unionised unlike their fellow workers in larger factories. The left largely failed to include them or substantially attract their support, leading them to feel "politically peripheral." ${ }^{12 .}$

Changes in the world economy can be considered the second fundamental factor that contributed to the NL's upsurge. Economic globalisation and the collapse of communism radically mutated the Northern Italian communities and the way they channelled their political demands. The economic changes in particular revealed the central position within the economic system of new social classes that now claimed more political influence. Traditional parties could not provide it and many northern entrepreneurs, self-employed professionals, and workers became the constituencies that, at the same time, created and were represented by the NL. Understanding the demands of this "new productive class, the most dynamic in the country,"13 allowed the NL to establish itself as the spokesperson for the richest area of the country.

\section{The Northern League's road to success: North versus South}

The leadership of the NL was able to interpret the needs and demands of the northern society through new ideological lenses. The League drew upon existing feelings of mistrust and 
discontent against the political class, the inefficient state bureaucracy, the fiscal system, big business, Southerners and foreign immigrants in order to set forth its own project. In the white deep North many had been upset with the DC-led governments for many years, but feared changing allegiance, but the collapse of communism eliminated the traditional enemy and between 1987 and 1992 most of the votes that the NL received came from former DC supporters.

The NL understood that a different political cleavage replaced the traditional left/right ideological struggle and contributed to deepen it. As it became evident that purely ethnic politics would not win much support, Bossi watered down the early ethnic project of the leghe autonomiste. Perceived ethnic and linguistic differences among regions had been used by the leghe autonomiste to win the electorate approval for administrative decentralisation, but the basis for the League's project relied much more heavily on economics and social behaviour. However, the NL used those 'differences' to strengthen its political discourse. The feelings of mistrust toward Southerners accompanied by a vast array of stereotypes were instrumental in differentiating the Northern peoples from the Southerners, thus creating the conditions to delegitimise the country's centralist constitutional structure. If the Southerners and Northerners were different, then each people should have had the right to self-determination. The League proposed the creation of a federal state, arguing that local differences had always been a characteristic of the country for historical reasons and the 1861 unification did not make them disappear.

The leader of the NL Umberto Bossi identified the North as the bedrock of hardworking, wealth-producing and taxes-overburdened people who were sustaining the entire Italian economy, since the South was subsidised through wasteful money transfers. The specifics of this policy were always a matter of contention, but the policy itself had found support across the political board. On the contrary, the Northern League questioned the policy at its core and proposed a radical alternative: eliminate all state-aid and, through federalism, force the South to find its own road to economic and social development. According to the League, the wealth 
produced in the North should have been invested and spent for the benefit of the local communities.

The Northern League's fundamental goal is to gain substantial political, economic, and administrative autonomy for the northern regions. In order to achieve this result, Bossi reversed the terms of the centennial debate on the 'Southern question.' Ever since the 1861 unification all parties had to deal with the question of economic and social development in the more backward South. However, the gap between North and South steadily increased. The economic boom of the 1960s was felt very superficially in the Southern regions. Vast-scale industrialisation did not take place, the presence of organised crime discouraged private investments, and state money was used to foster clientelism while scores of people emigrated in search of employment. On the contrary, the northern regions developed rather quickly thanks to a mix of favourable geographic position, good local political administration, entrepreneurial spirit, and cheap Southern immigrant labour. In the early eighties a huge public deficit provoked an increase in taxation, creating an atmosphere of discontent in the North toward the central government since the money raised to fill the state empty coffers impeded further economic growth. Moreover, an overwhelming number of Southerners held posts in the state bureaucracy, drawing criticism from Northerners who privileged the private sector and who felt they financed an inefficient and corrupt bureaucracy.

According to this picture, Bossi claimed that the real national question was the 'Northern question'. The central government could not dismiss Northerners' demands that would facilitate economic growth: the richest regions should be encouraged to continue their drive to prosperity and to be competitive on world markets. In order to do so, the huge network of small and medium sized firms demanded more infrastructures, sharp decrease in taxation, and less regulation. At the same time, workers demanded lower taxes or better services. The younger elements of the working class were particularly keen to listen to the NL's political discourse. The answer to both constituencies, according to the League, is extensive federal reforms. The League 
believes that local municipalities should keep most of the money raised with taxation and invest it locally as new federal laws would provide for an extension of powers on many matters, ranging from policing to school curricula. The old system based on transfers from the central government should be abolished.

The Northern question has occupied the political debate since the late 1980s and has shifted the attention on areas of the country previously taken into very little consideration. The economic and social North/South fracture substituted for the old left/right framework. However, this would not have been enough to guarantee visibility to the NL if it had not been connected more deeply to local realities. The previous experience of the leghe autonomiste revealed its importance in terms of community building. The local dialect, the supposed common ethnic background, the same attitude toward hard work and respect for basic civic rules are all elements that bonded with the economic discourse. The two discourses mutually reinforce each other. The League suggests that a high degree of political and economic autonomy is the only possible solution for Italy's problems.

The issues that the Italian society was facing were complex and called for a restructuring of all aspects of the country from politics to economics. The Northern League succeeded because it offered simple solutions for valid complaints, which responded to long-standing problems. The NL was able to connect those solutions to a wider social, economic, cultural, and political project. Local traditions, exclusion of foreigners variously identified, heavy limitation of state intervention, low taxes, privatisation of public services, and cultural conformity are the pillars of that project.

\section{The Northern League's issues}

The issues that granted visibility to the League and that helped it build a vast consensus can be traced back to the fundamental challenges facing Europe since the late 1980s. The renaissance of nationalism accompanied the collapse of internationalist socialist ideology and 
Western Europe was not immune to it. Nationalist parties rose to prominence all over Western Europe, even if they took different forms, sponsored different programs, and enjoyed different degrees of electoral success. In particular, we must mention, the Austrian Freedom Party, the Belgian extreme right movement Vlaams Blok, as well as other formations in Germany (DVU, Republikaner), Denmark, and Sweden. All these political formations benefited from the 'new' cultural importance given to the idea of Nation and national belonging. In a sense, nationalism substituted for the need of self-identification of people that previously was implemented by other political ideologies.

The end of socialism represented also a defeat for the working class. It is true that most Western European leftist parties had distanced themselves from Moscow well before 1989, but many past victories in terms of labour-capital relations had been gained by the working class thanks to the existence of an alternative economic model. The left's inability to respond to the post-1989 challenge by rethinking a socialist platform opened the door to a right wing, nationalist approach to labour-capital relations. As unemployment soared and more foreign labour came to the EU, the far right seized the opportunity to put forth its agenda. At the same time, the United States with its impressive economic growth and low unemployment is both the example and the promoter for neo-liberal policies. Since the neo-liberal model is so imposing and since the European left has no clear alternative to it, there is a political vacuum that can be filled.

The intertwined forces at play have given voice to nationalist parties. The Northern League comes out of this 'political family' and it builds support on the same issues that are at the core of right-wing parties' campaigns. However, distinctions have to be made concerning the solutions it proposes for specific Italian problems. Concerning the question of immigration, the NL calls for very restrictive measures and sees it as a 'security problem'. Immigrants are largely identified with crime, but in many of its strongholds there are large communities of immigrants who provide much needed labour ${ }^{14}$. The anti-immigrant stance of the Northern League may thus 
seem paradoxical, but it can be explained by looking at the economic neo-liberal model they have in mind. The NL is favourable to provide cheap labour to the small and medium-sized Northern enterprises as long as these foreign workers are made 'invisible' in the communities where they live. They are not perceived as potential citizens, but as a necessary evil that has to be imported in order to sustain economic growth. On this note, Umberto Bossi recently encouraged Northern Italians to have more babies so that in the future foreign labour will not be necessary any longer.

Another issue on which the League built its success was the question of taxes. Taxation in Italy has always been elevated in order to sustain an expensive welfare system, but two features were distinctive of Italy: 1) poor performance of many social services and 2) a scandalous amount of tax evasion. The government therefore heavily taxed verifiable incomes (i.e. salaries), with employees accounting for most of the state revenues. In exchange for heavy taxation, employees in the public sector enjoyed high job security and retirement privileges. Workers in large private firms enjoyed a good level of social protection as well thanks to strong trade unions.

With the new economic order, the 'deep North producers' began complaining that indirect taxes were too high, services too poor, and infrastructure too inefficient to allow them to cope with the requirements of economic globalization. Moreover, the feeling that tax money was spent in wasteful projects in the South and used to feed an inefficient bureaucracy accelerated the pace of fiscal protest. The equation 'too much state, too much waste, and too many Southerners' was simple to make. The League correctly interpreted the northern entrepreneurs'demands and proposed that taxes should be lowered and, more importantly, spent in the territory where they were paid. However, the real ability of the League consisted in underplaying the conflict between employers and employees, uniting them under the banner of federalism. The targets were Southerners who enjoyed fiscal exemptions of all sorts, lived off state handouts, and occupied the majority of state jobs. The League's solution fitted perfectly in the social and economic context of the "deep North". Bossi proposed that tax money should be kept where it was 
produced through a federal reform of the entire tax system, benefiting both employers and employees in the North. If the money wasted in the South could be used instead to have more efficient public services and higher investments in the North, then the whole Northern society would benefit from it.

The two issues mentioned above are tightly intertwined and are the main components of a wider program of revolutionary changes that the League wants to introduce in the political and economic life of the country. The NL was and is not a 'single-issue' party and has become a durable player in Italian politics thanks to an encompassing vision of how Italy should be. The League built its success by addressing the demands of constituencies whose needs had been previously omitted and was able to fit them in a vision of a better society that other parties lacked. The way those issues were tackled demonstrates that the NL fit perfectly with other rightwing movement across the continent. Oversimplification and easy categorisations for the identification of enemies on the base of their ethnicity or geographic background were the League's weapons together with the servile attitude toward businesses.

\section{The Padanian identity: from ethnic politics and back}

The Northern League is a territory-based political organisation whose fundamental goal is to represent the interests of the Northern Italians. Its electoral support has been widespread in all northern regions excluding perhaps Emilia-Romagna where making headway was particularly difficult. Despite its clear territorial base and 'its nationalist' project aimed at defending the North of Italy, Bossi's Northern League attempted to steer away from ethnic identity. When Bossi finally reunited in 1989 all the leghe autonomiste within the one single political organisation, he clearly spelled out that traditional enmities among regional movements in the name of ethnolinguistic differences should be set aside in favour of a more comprehensive outlook. Thus, economic and social similarities across all northern regions took over and were utilised to promote the 'Northern question.' According to the NL, the North is an economic and productive 
reality rather than an ethnic, religious or linguistic entity fighting for recognition and autonomy from the central government.

In the early 1980s there existed a number of small, regionally-based political parties that advanced the cause of regionalism through ethnic and linguistic identification on the mould of the Union Valdotaine (UV) and the Sud-Tirole Volks Partei (SVP) that in the aftermath of World War II secured the status of regions with a special statute for Valle D'Aosta and Trentino AltoAdige, where a French-speaking and a German-speaking minority lived. These leghe autonomiste demanded more autonomy for the existing regions on the base of local differences that distinguished each region from the other. The leaders of the leghe autonomiste underlined the importance of the local dialect, emphasised local cultural traditions and flirted with ethnicity to justify their demands for increased political and administrative autonomy. Once autonomy was granted, it would have beneficial effects on the local economy thanks to the decentralisation of important decision-making processes. Despite their efforts, the leghe autonomiste were not able to gather any substantial support and remained marginal actors on the political stage. One reason for their lack of success was the firm grip of traditional political parties on the political agenda; another was the clash of personalities that led to internal squabbles. Moreover, Italy was still locked in the ideological struggle and the international environment had considerable repercussions in stalemating domestic political life. However, the apparent ideological deadlock and its electoral consequences cannot be the only reason for the lack of success of the leghe autonomiste as other new political formations had been able to gather some support (i.e. the Greens) despite strong 'systemic' pressures. The leghe autonomiste tried to "transform a geographic and administrative point of reference (the Region) into the basis for a deep and intense identification"15 and failed. Thus, the lack of clear-cut linguistic, religious and ethnic criteria, which would be the founding base for a common identity for all Northerners in contrast with a common identity for all Southerners, contributed to the setback of the leghe autonomiste. 
Bossi abandoned, albeit not entirely, the ethnic project and economic differences between North and South became the main political theme of the Northern League. This strategy proved successful and the League "proposed itself as the defender of simple peoples (the hardworking Northerners) considered according more to criteria of social and economic homogeneity than on ethnic basis." ${ }^{16}$ The ethno-linguistic discourse was maintained in a mild form to satisfy those within the party who had been supporters of the leghe autonomiste and it served the purpose of legitimising the radical economic and political reforms that the NL advocated. The picture changed in early 1995 with the launch of the campaign for Padanian identity. This was both an answer to the internal crisis of fall 1994 when the NL split over the decision to abandon the Berlusconi-led government and a new political challenge to all other parties that by the time had caught up with the NL on the issue of federalism. Thus, there are two different but interlocking reasons for the search of a strong ethnic identity not only as a means to achieve concrete goals, but also almost as an end in itself.

In the fall of 1994, Umberto Bossi decided to withdraw the League's support to the Berlusconi-led government, since the League's attempts at federalising the country had been discarded. The NL split over the decision to leave the coalition and Bossi attracted accusations of treason from his former allies and from a score of his own party members. He responded to this crisis by "proposing almost obsessively the central elements of the original League's identity, refusing to enter any coalition." ${ }^{17}$ The cement that would hold the party together, limit the outflow of militants and increase support after the 1994 electoral losses was the launch of Padania and Padanian identity. Through a selective reinterpretation of Italian political life and history, all Northerners were held to have a common Celtic ethnic background that was different, and therefore opposite to Southerners ethnic composition. This is not true as all Italians (with the exception of the German, French and Slovene minorities) have the same common mixed ethnic origin. Language is also the same for all Italians, but local dialects are indeed very different from one another and are widely used in everyday life. However, they are not languages and there are 
just as many differences among northern dialects as there are between Southern and Northern ones. Despite this, the NL attempted to found a common ethnicity for all Northerners, give it historical legitimacy and campaign on it for the right to self-determination. This selfdetermination could occur through federalism or secession. Much effort was put into building a Padanian identity: the creation of a Northern parliament, the formation of a secessionist government, the organisation of a referendum for independence in the North, the launch of Padanian TV and radio stations, and the promotion of annual Celtic Games ${ }^{18}$. All these steps were accompanied by the new symbols of Padanian identity. The traditional symbol of the warrior Alberto da Giussano was replaced by the "Sun of the Alps", the colour green substituted for the original red and white, and the North was referred to as Padania and not as the Northern Republic.

The launch of Padania was not simply a means through which reinvigorate militants and supporters, but was also a fundamental shift in the political outlook of the Northern League vis a vis the other political parties. For a considerable time, the Northern League enjoyed a substantial advantage over all other political formations in terms of issues it stood for and in terms the political vision of socio-economic cohesion it purported. All this had changed by the mid-1990s as most parties supported decentralisation (even though not to the League's extent), fiscal reforms, the liberalisation of the economy, a halt to illegal immigration, a tough stand against organised crime and the drive to achieve EMU. Suddenly, it seemed that the edge the League had concerning issues and vision of a new society was lost as almost every party had closer policypositions. In order to re-gain that edge, Bossi decided to play the "identity card". The ethnic discourse that was in the background and the rhetorical role it played in gathering support from all sectors of the Northern society was let out in the open. An intense campaign of Padanian nationalism began in 1996 and accompanied a return to grassroots politcs in preparation for the April 1996 general election. Thus, the NL ran alone and fared surprisingly well at the April 1996 national election, taking 23 per cent of the votes in the North (excluding Emilia-Romagna). 
Despite the stunning result, the NL was marginalised in Parliament, as its votes were not decisive in tipping the balance between the centre-right and the centre-left coalitions.

The electoral results encouraged Bossi to accelerate and deepen the process of Padanian nationalism; disregarding concrete stands on specific policies and privileging an all-embracing ethno-nationalist approach to every matter of political significance. From then on, the NL acted according to ethnic criteria rather than on socio-economic ones, returning to the leghe autonomiste original platform. Unfortunately for the League, the northern electorate was not ready for such a change. The lack of clear-cut ethnic criteria on which to build Padanian nationalism did not allow the League to strike a chord within the larger electorate that was more concerned with concrete problems. The strength of the League had been to privilege economics and social behaviour over ethnicity and reversing the discourse did not pay off. A mild northern nationalism had been useful in conveying the League's message regarding the necessity for federal reforms, but the new Padanian nationalism was much too strong and self-referential to appeal voters.

As a consequence of this intensive campaign of Padanian nationalism, the NL found itself in very awkward positions with respect to specific issues. One of the first policy reversals occurring in the name of national identity was the critical stance on the European Union and EMU, when in earlier times it had been the only party to take Europe seriously in Italy. Then came the abandonment of federalism as the ultimate League's goal and it was substituted for by secession, with threats of armed violence to achieve it. The refusal to choose stable alliances with either the centre-left or centre-right disoriented many militants as giving conditional support to either one coalition to extract the maximum of advantages was typical of parties during the First Republic and had been criticised many times over by the Northern League leadership. Finally, the open support for Milosevic during the war in Kosovo was the latest of the NL's political contradictions. The confusion that reigned among militants over these sudden changes and reversals had negative repercussions in electoral terms and created disaffection to the leadership 
within the movement. Many elected officials left the party or were thrown out in an all-out political struggle among the different factions. The great emphasis on Padanian nationalism backfired and Bossi reversed it by entering into a new coalition with the centre-right. This alliance has revived the League's electoral fortunes and it has made it again a leading actor on the Italian political scene.

\section{An assessment of the Northern League}

The Northern League has not yet succeeded in obtaining a high degree of autonomy for the northern regions. However, its presence in the political system changed the structure and the content of Italy's politics. The NL was in fact able to achieve significant results, directly or indirectly, both for itself and for the whole country and it provided, since its onset, a valid critique of the Italian political system.

The question of excessive state spending, the poor performance of public services, the lack of decentralised decision-making, the increasing gap between North and South, the low international status of the country, the waste, and the corruption were issues that traditional parties were not tackling. However, the NL is "efficient in its role as a channel of representation of discontent, but it is much less effective as a political subject offering solutions and administration." ${ }^{19}$ It seems that the Northern League is well suited for 'destructive' politics, but ill-suited for "constructive" ones. On the one hand, the NL raised fundamental issues that the political system refused to take into account and that were causing increasing detachment between the citizens and the traditional parties. On the other hand, the NL was unable to formulate a coherent and effective political response. Presenting itself as a party of strong "ethno-nationalist" 20 identification, it inevitably tends to be exclusive and racist rather than inclusive, and antagonising rather than accommodating. Thus, the NL is able to channel resentment, but unable to offer valid policies for effective change. 
Despite not having achieved any fundamental results in terms of decentralisation, the League deserves credit for some positive changes that occurred during the 1990s. First of all, the NL contributed to and accelerated the dismantling of the previous putrid system. Bossi and the rest of the leadership denounced the corrupted party system and the involvement of all leading political figures in contributing to the decay of the country's politics and economics: operation "Clean Hands" proved them right. Thus, the League accelerated the inevitable end of a political system that was unable to meet new challenges and to innovate. However, it was the old political class that favoured the enrichment of the entrepreneurial northern class. Bossi willingly forgets that the League has its stronghold where the DC used to be all-powerful and the DC is the same party that controlled the state and caused many of the problems he was pointing at. The NL was able to hide the most controversial and complex aspects of Italian political and economic development in order to construct a picture where it was easy to identify Southerners as scapegoats.

A second positive feature is the introduction of concepts such as federalism and administrative and fiscal autonomy. Slow 'Roman' bureaucracy had left many local communities' needs unanswered for a long time and centralisation of the decision-making process provokes enormous disadvantages, in particular in a rapidly changing world and dynamic economy. The NL was the first political movement to propose a solution to the problem of centralized decision-making. The debate over the transformation of the country into a federal state and the electoral success it obtained forced all other parties to embrace, at least on paper, the cause of decentralisation. This debate is very healthy for Italian democracy and represents a step ahead in the right direction both to fight people's disaffection toward politics and to practically improve civil service's performances. Following the NL's pressure, some elements of federalism have been introduced through the existing administrative bodies. The regions have been empowered with the possibility to raise some taxes and spend the money as they think best. 
However, such low-profile reforms did not lead to a far-reaching federal decentralisation and the NL still keeps the pressure on the central government to obtain extensive federal reforms.

Thirdly, the League's strong anti-Southern polemics triggered a positive reaction in the South. This may seem paradoxical, but the League's success might have indirectly contributed to the awakening of the South. In the last few years, new mayors and local administrators pushed for radical changes in governing their municipalities, calling for an end of patronage and clientelism, fighting with the central government for more financial autonomy, and organising to obtain special powers to develop their areas. According to many of them decentralisation is necessary to improve their performances in providing local communities with better services. Thus, those who seemingly had the most to lose with its introduction have taken up the federal discourse.

Finally, the League began underlining the importance for Italy to play a greater role in Europe. With the deepening of economic integration, it was imperative for Italian economy to restructure and to participate to the EMU. The League began pressuring public opinion and the other parties to realise that the European construction was far more important than petty and endless 'national' issues. Despite recent criticism on how monetary union was achieved, the League remains committed to the European project ${ }^{21}$.

If, on the one hand, the Northern League contributed to bring about positive changes, on the other hand its actions had a tremendous disruptive impact on the political system and on society. While the old political system was able to reach compromises through the mass parties in order to satisfy the demands of all actors, the League's presence made this search for compromises more difficult. The ethnic discourse to fuel economic and political demands have been very divisive. Feelings of mistrust and racism toward Southerners had always been present in Italian society, but the NL exploited them to a greater extent, as all problems are blamed on Southerners. This triggers a dangerous identification with the entire civil service that in turns reflects into mistrust and hatred for all state's institutions. It is true that Bossi speaks of peaceful 
means to achieve "freedom", but in more than one occasion he also spoke of guns, bullets, and militias. The very existence of the "green shirt" militia clearly points out to a militaristic organisation of the party.

Secondly, there are dangerous attempts to test the limits to which the NL can go with its actions before triggering a reaction from the central government. Forming a secessionist Parliament and a provisional government would be considered subversive acts in any other country, but the NL was able to carry them out without being sanctioned. The central government wants to avoid any confrontation, but it risks to underestimate the danger posed by the NL to the democratic process and Italy had known institutional breakdowns in the past.

Finally, the NL is key to the introduction of American style capitalism in Italy. The entrepreneurial business class in the North needs the introduction of a laissez faire market to remain profitable in the era of globalization and it needs a supine political power. The NL offers both. Without the weight of the South, the rich North will be able to keep the pace of the strongest world economies through the Americanisation of its labour and financial markets. The future government in the North would undoubtedly favour the entrepreneurial class, providing an ideal social and cultural environment purified of undesired 'foreign' elements. What is really interesting is the ability of the League to attract sectors of the northern blue and white-collar working class. The alliance of capital and labour against the central government has been cemented through the ethno/nationalist political discourse. However, the "deep North" entrepreneurial class is not sincerely committed to the NL nationalist project in all of its aspects. It is far more interested in the establishment of a laissez-faire economy than in the promotion or defence of the ridiculous Padanian identity. The economic needs of this class can also be satisfied by other political forces promoting extensive neo-liberal reforms as shown by the support that Berlusconi received among the Northern entrepreneurs at the 1994 election. Many of them eventually shifted back to the NL when Berlusconi proved unwilling and unable to deliver what they expected. The ethnic, nationalist discourse is used by the NL to hold labour and capital 
together in the name of Padanian identity, but capital is ready to betray the NL project: it is more than willing to hire cheap foreign labour when given the opportunity or to shift production in low-labour cost countries. At the same time labour, particularly in the private sector and not limited to blue-collar workers, holds on to the ethnic project as a means to avoid foreign labour competition and to enjoy higher salaries if the South is dropped and taxes reduced. This situation entails that many workers are blackmailed into accepting harder working conditions, limitations of various sort (vacations, permits, and so on), and lower pay if they want to keep or find a job even in times of low unemployment in the North. Since clear leftist alternatives are lacking, it is not surprising they are far more committed to Padania than their capital counterpart.

\section{$\underline{\text { Conclusion }}$}

The Northern League has been one of the protagonists of the changes that Italy underwent in the last ten years. For fifty consecutive years the same parties had run the country, guaranteeing economic growth and political stability while installing a centralised and corrupt system of social and economic relationships. With the waning of the left/right cleavage, new issues and demands began to appear, forcing parties to rethink their own position. Thus, the dormant territorial conflict awoke as the rich northern regions began to feel that profound political and economic reforms were needed if they were to retain their successful economic position. The NL became their vehicle of political expression, calling for federalism, fiscal autonomy, drastic reduction of welfare state benefits, and introduction of American-style market competition, selective foreign immigration, and a significant effort to participate to the construction of a "Europe of Regions". The NL blamed the political class for waste and corruption, accused the big industries and the trade unions of strangling the small and medium entrepreneurial spirit for their own mutual benefits, pointed the finger to the laziness of Southerners, and denounced the extension of state interference in people's lives. 
The failure of the Padanian project and the political marginalisation the NL has suffered since 1996 did not bury the party. In fact, the 'hard times' showed that the NL can count on very committed members and supporters who follow without questions the contradictory decisions of the leadership. The votes the NL can provide to the centre-right coalition are decisive in many constituencies and the renewed alliance with Berlusconi will allow the Northern League to become a prominent player yet again. The needs and demands of the classes the NL represents have not been met and are likely to play an influential role in the upcoming elections. After having reversed its electoral downfall in the recent regional election, the NL is poised to return to power in Rome and to finally deliver federalism to the country. 
${ }^{1}$ Among this type of parties, the Radical Party and the Greens are worthy of mention. The Radical Party enjoyed a successful spell in the mid-seventies under the leadership of Marco Pannella, while the Greens had a significant electoral in the early eighties. Both parties still exist today, but they have a marginal role and small following.

${ }^{2}$ To this effect, many constitutionalists pointed out that there existed a non-written rule, the conventio ad excludendum, by which all existing parties would form a Grand Coalition rather than letting the PCI come to power. Obviously, the Pci would have had to gain more than $50 \%$ of the votes if it wanted to run the country.

${ }^{3}$ M. Paci, 'Ceti emergenti, aree territoriali e mobilitazione politica', in N. Negri and L. Sciolla (eds.), Il Paese dei Paradossi, Roma, 1996, La Nuova Italia Scientifica, p.237.

${ }^{4}$ For a detailed account and explanation of Italian democracy's paradoxes, see J. LaPalombara, Democracy Italian Style, New Haven, 1987, Yale University Press, pp.1-308.

${ }^{5}$ Seymour Martin Lipset and Stein Rokkan, 'Cleavage structures, party systems, and voter alignments: an introduction', in S. M. Lipset and S. Rokkan (eds.), Party systems and voter alignments: cross-national perspectives, New York, 1967, The Free Press.

${ }^{6}$ Ibid., 43.

${ }^{7}$ L. Costantini, Dentro La Lega. Come nasce, come cresce, come comunica, Roma, 1994, Koine' Edizioni, p.35.

${ }^{8}$ Renato Mannheimer, 'La crisi del consenso per il partiti tradizionali', in La Lega Lombarda Renato Mannheimer (ed.), Milano, 1991, Giangiacomo Feltrinelli, p. 17.

${ }^{9}$ Voting patterns in Italy remained quite stable for long periods of time and most geographic areas were identified and referred to according to the dominant political party. Thus, there were 'red' districts, cities or regions where the PCI was dominant and 'white' districts, cities or regions where the DC was by far the leading party.

${ }^{10}$ G. Lago, 'Qui Veneto, l'antica voglia di autonomia', La Repubblica 25/4/1998, p. 1.

${ }^{11}$ M. Revelli, 'Economia e modello sociale nel passaggio tra fordismo e toyotismo' in Appuntameni di fine secolo, P. Ingrao and R. Rossanda (eds.), Roma, 1995, Manifestolibri, pp. 165-225.

${ }^{12}$ I. Diamanti, Il Male del Nord-Lega, localismo e secessione, Roma, 1996, Donzelli Editore, p. 90.

${ }^{13}$ Paci, op. cit., p. 236.

${ }^{14}$ A. Carini, 'Senza di loro fabbriche chiuse, il Nordest chiede piu' immigrati', La Repubblica 19/01/1999, p. 4.

${ }^{15}$ R. Biorcio, La Padania Promessa. La Storia, le idee e la logica d'azione della Lega Nord, Milano, 1997, Il Saggiatore, pp. 35-103.

${ }^{16}$ U. Bossi and D. Vimercati, La Rivoluzione. La Lega:storia e idée, Milano, 1993, Sperling \& Kupfer, p. 101.

${ }^{17}$ Biorcio, op. cit., p. 84. 
${ }^{18}$ A. Sema, 'Contro Roma Bossi inventa lo sport padano', Limes, rivista italiana di geopolitica, n. 1 (1998), p. 151.

${ }^{19}$ Diamanti, op. cit., p.110.

${ }^{20}$ Biorcio, op. cit., p.20.

${ }^{21}$ La Padania, 29/3/1998, p. 11. 